\title{
Above- and Belowground Development of a Fast-Growing Willow Planted in Acid-Generating Mine Technosol
}

\author{
M. Guittonny-Larchevêque* and S. Lortie
}

\begin{abstract}
Surface metal mining produces large volumes of waste rocks. If they contain sulfide minerals, these rocks can generate a flow of acidic water from the mining site, known as acid mine drainage (AMD), which increases trace metals availability for plant roots. Adequate root development is crucial to decreasing planting stress and improving phytoremediation with woody species. However, techniques to improve revegetation success rarely take into account root development. An experiment was conducted at a gold mine in Quebec, Canada, to evaluate the establishment ability over $3 \mathrm{yr}$ of a fast-growing willow (Salix miyabeana Sx64) planted in acid-generating waste rocks. The main objective was to study root development in the soil profile and trace element accumulation in leaves among substrates varying in thickness $(0$, 20 , and $40 \mathrm{~cm}$ of soil) and composition (organic carbon [OC] and alkaline AMD treatment sludge). Trees directly planted in waste rocks survived well $(69 \%)$ but had the lowest productivity (lowest growth in height and diameter, aerial biomass, total leaf area, and root-system size). By contrast, the treatment richer in OC showed the greatest aerial biomass and total leaf area the first year; the thicker treatment resulted in the greatest growth in height and diameter, aboveground biomass, and root-system size in both the first and third years. Willow root development was restricted to soil layers during the first year, but this restriction was overcome in the third year after planting. Willow accumulation factors in leaves were below one for all investigated trace metals except for zinc $(\mathrm{Zn})$, cadmium ( $\mathrm{Cd}$ ), and strontium. For $\mathrm{Cd}$ and $\mathrm{Zn}$, concentrations increased with time in willow foliage, decreasing the potential of this willow species use for phytostabilization, despite its ability to rapidly develop extensive root systems in the mine Technosol.
\end{abstract}

\section{Core Ideas}

- Salix miyabeana grew roots extensively in shale waste rocks, even if AMD generating.

- Root development in waste rocks was delayed at least 1 yr under soil layers.

- A soil layer of $40 \mathrm{~cm}$ maximized root system size after $3 \mathrm{yr}$.

- Soil layer thickness rather than organic matter content determined sustained productivity.

- Salix miyabeana accumulated $\mathrm{Cd}$ and $\mathrm{Zn}$ in foliage over time, especially with soil layers.

Copyright $\odot$ American Society of Agronomy, Crop Science Society of America, and Soil Science Society of America. 5585 Guilford Rd., Madison, WI 53711 USA.

All rights reserved.

J. Environ. Qual. 46:1462-1471 (2017).

doi:10.2134/jeq2017.03.0128

This is an open access article distributed under the terms of the CC BY-NC-ND license (http://creativecommons.org/licenses/by-nc-nd/4.0/).

Received 6 Apr. 2017

Accepted 18 Sept. 2017.

*Corresponding author (marie.guittonny-larcheveque@uqat.ca).
W OODY SPECIES planted in man-made substrates like Technosol (Chesworth and Spaargaren, 2008) frequently undergo planting stress (Grossnickle, 2005), and adequate root development is crucial to their establishment. The efficiency of their water and nutrient uptake depends on the size and distribution of root systems, which affect the volume of the substrate they penetrate, as well as on the contact surface of fine roots with the substrate and their hydraulic conductivity (Comas et al., 2013; Grossnickle, 2005). However, studies dealing with plantings on soils composed of industrial waste typically evaluate revegetation success based on aerial productivity or health indicators (Emerson et al., 2009; Kost et al., 1998; Landhäusser et al., 2012; Mosseler et al., 2014; Pietrzykowski et al., 2015; Sloan and Jacobs, 2013) and rarely account for root development (Guittonny-Larchevêque et al., 2016; Wagner et al., 2007).

Certain characteristics of mine wastes can prohibit root growth, including a lack of organic matter (OM) and soil organisms, extreme $\mathrm{pH}$, and elevated electrical conductivity and trace metal and metalloid concentrations (Tordoff et al., 2000). Over the life of a mine, waste rocks are often piled tens of meters high, especially in large, open-pit mines. If the rocks contain sulfide minerals, such as pyrite, these minerals undergo weathering when exposed to atmospheric conditions, which produces acid mine drainage (AMD) (Aubertin et al., 2002), with a concomitant increase in trace element mobility and availability to plant roots (e.g., aluminum [Al], chromium [Cr], manganese $[\mathrm{Mn}]$, and zinc $[\mathrm{Zn}])$ (Markert et al., 2000). Once in the plant, trace metals and metalloids can be phytotoxic, depending on their tissue concentrations and plant tolerance strategies (Baker and Walker, 1989). Acid mine drainage reactions also increase electrical conductivity in the waste, which can decrease water absorption by roots (Munns, 2002).

Moreover, during the mine's life, AMD-contaminated water can be actively treated by the addition of lime in the form of calcite or dolomite. For example, lime is added to precipitate iron $(\mathrm{Fe}), \mathrm{Al}$, and $\mathrm{Mn}$ and to coprecipitate and/or adsorb

M. Guittonny-Larchevêque, Research Institute on Mines and Environment-Univ du Québec en Abitibi-Témiscamingue, 445 Bd de I'Université, Rouyn-Noranda (QC) J9X 5E4 Canada; S. Lortie, Westwood mine, IAMGOLD Corp., C.P. 970, RouynNoranda (Québec) J9X 5C8 Canada. Assigned to Associate Editor Markus Grafe.

Abbreviations: AMD, acid mine drainage; OC, organic carbon; S2020, 20-cm layer of soil mixed with $20 \%$ peat soil; S2040, $20-\mathrm{cm}$ layer of soil mixed with $40 \%$ peat soil; $54020,40-\mathrm{cm}$ layer of soil mixed with $20 \%$ peat soil; S20LS, $20-\mathrm{cm}$ layer of soil mixed with $20 \%$ peat soil above a 20 -cm layer of water treatment sludge; $\mathrm{W}$, direct planting in waste rocks. 
metallic cations (lead $[\mathrm{Pb}]$, cadmium $[\mathrm{Cd}]$, copper $[\mathrm{Cu}], \mathrm{Zn}$ ) and oxyanions (arsenic oxide $\left[\mathrm{AsO}_{4}\right]$, selenium oxide $\left[\mathrm{SeO}_{4}\right]$, phosphorus oxide $\left[\mathrm{PO}_{4}\right]$ ), producing alkaline water treatment sludges (Ritcey, 1989). These sludges are stored as a waste on mine sites, but in the case of limited available soil for revegetation, reusing them as a growing substrate can be an option. Indeed, they have been used as fertilizers for the slow release of sulfur $(\mathrm{S})$, nitrogen $(\mathrm{N})$, and phosphorus $(\mathrm{P})$ and as amendments to stabilize metal-contaminated soils (Rakotonimaro et al., 2017). Their use as an alkaline barrier between plant roots and waste rocks could decrease some trace element mobility toward plants.

Woody plants such as Salicaceae are recommended for phytoremediation of metal-contaminated soils worldwide because they produce high biomass even under conditions of metal phytoaccessibility (Lebrun et al., 2017; Marmiroli et al., 2011). Willow (Salix sp.), in particular, seems well adapted to planting on mine substrates (Mosseler et al., 2014). Some fast-growing clones, like Salix miyabeana Sx64, seem tolerant to low $\mathrm{pH}$ and saline conditions (Hangs et al., 2011; Mirck and Volk, 2010) and to elevated concentrations of some trace metals (Harada et al., 2011; Zhivotosky et al., 2011). However, some willows have been demonstrated to accumulate metals that originated from the substrate into their leaves (Robinson et al., 2000), particularly $\mathrm{Cd}$ and $\mathrm{Zn}$ (Labrecque et al., 1995); trace metal accumulation patterns are clone- or species dependent (Boyter et al., 2009).

Combining stress-tolerant plants with substrate improvement can increase revegetation success. In modern mines, overburden is usually saved to be layered above mine wastes for revegetation purposes (Cooke and Johnson, 2002). Because downward root development in the mine wastes can be restricted (GuittonnyLarchevêque et al., 2016; Larchevêque et al., 2013), it is important to design soil layers that provide enough volume (i.e., thickness) and quality (i.e., through avoiding compaction and providing organic matter) for roots to access water and nutrients adequately. Planting stress can be reduced through organic amendment that improves soil structure (porosity, aeration, and water-holding capacity) and, consequently, creates better conditions for root development in addition to nutrient release (Guittonny-Larchevêque and Pednault, 2016; GuittonnyLarchevêque et al., 2016; Larchevêque et al., 2013).

We conducted an experiment over 3 yr to evaluate the ability of a fast-growing willow clone (Salix miyabeana Sx64) to establish in soil layers above acid-generating waste rocks from a gold mine in Quebec. The main objective was to study root development in the soil profile among substrates varying in thickness and composition (i.e., organic matter content and the presence of an alkaline AMD sludge layer) and to relate it to trace element accumulation in leaves. Our working hypotheses were that (i) root development will be limited in waste rocks; (ii) the thicker or organic carbon (OC)-richer the soil layer, the less will be the colonization of underlying waste rocks by willow roots; (iii) thicker soil layers will decrease trace metal accumulation in willow because a smaller proportion of roots will be in contact with the waste rocks; and (iv) the presence of an alkaline sludge layer will decrease trace metal accumulation in willow.

\section{Materials and Methods}

\section{Site Description}

The experiment took place at the Westwood mine site $\left(48^{\circ} 15^{\prime} \mathrm{N}, 78^{\circ} 32^{\prime} \mathrm{W}\right)$ in northwestern Quebec, Canada. This underground gold mine belongs to IAMGOLD Corporation and opened in 2013. Until 2009, the site was used by the Doyon gold mine, which extracted waste rocks from an open pit at the beginning of the mine life and then operated underground. The waste rocks, which were extracted from shale bedrock, were stored in a waste rock dump and were also used to construct roads on the Doyon mine site. The typical forest vegetation that surrounds the mine includes Pinus banksiana Lamb., Picea mariana (Mill.) Britton, Populus tremuloides Michx., Betula papyrifera Marsh., Larix laricina (Du Roi) K. Koch, and Abies balsamea (L.) Mill. In this boreal region, the growing season typically begins in mid-May and ends in October, with a mean temperature during the three warmest months (June, July, and August) of around 15 to $17^{\circ} \mathrm{C}$. The average annual temperature is $1.5^{\circ} \mathrm{C}$, and the average number of frost-free days is 97 . Mean annual precipitation is $929 \mathrm{~mm}$ (Government of Canada, 2017).

\section{Substrates}

The experimental plantation was established over a road made with Doyon waste rocks exposed to surface conditions for several decades. The waste rocks were characterized as acid-generating (Gélinas et al., 1994), which means that the acid-generating potential associated with sulfide minerals is greater than the neutralization potential of other minerals found in the waste rocks. Their mean total trace metal concentrations at the time of the experiment were found to be below Quebec's regulation thresholds for residential lands (Government of Quebec, 2017). The soil used as a planting substrate above the waste rocks was a sandy loam till (Dystric Brunisol) (Agriculture and Agri-Food Canada, 2010) excavated from a borrow pit on the mine site. Humus peat soil, excavated from a local bog, was used as an amendment to increase OC concentration of soil layers. The lime sludge used to make a layer between the waste rocks and the soil layer was collected from the bottom of water-treatment ponds. These ponds collected acidic water, to which lime was mixed to precipitate metals. Table 1 presents chemical characteristics of the fine fraction of the waste rocks $(<2 \mathrm{~mm})(\mathrm{W})$ as well as till soil mixed with peat soil (S2040, S2020, S4020, S20LS) and lime sludge. Mean trace metal concentrations found in the soils were below Quebec's regulation thresholds for residential lands; the lime sludge contained the greatest trace metal concentrations, with cobalt ( $\mathrm{Co}), \mathrm{Cu}$, and $\mathrm{Mn}$ exceeding Quebec's regulation thresholds for residential lands.

\section{Plant Material}

Willow stock was produced locally by a private nursery (Cellule des Coteaux, La Morandière, QC). It consisted of clonally propagated, 1-m long cuttings from Salix miyabeana Seemen, Sx64 clone. Planting was performed on 9 June 2014. Unrooted cuttings were planted to a depth of 20 to $30 \mathrm{~cm}$ in the substrates (Fig. 1). All cuttings were fertilized at planting with $15 \mathrm{~g}$ ammonium nitrate (34.5-0-0) and $15 \mathrm{~g}$ triple superphosphate 
Table 1. Chemical characteristics of the substrates at planting (June 2014) among treatments $(0-10 \mathrm{~cm} ; n=4)$ and in lime sludge. All values are expressed on a dry matter basis.

\begin{tabular}{|c|c|c|c|c|c|c|c|c|}
\hline \multirow{2}{*}{$\begin{array}{l}\text { Chemical } \\
\text { characteristics }\end{array}$} & & \multicolumn{7}{|c|}{ Treatment $\neq$} \\
\hline & & 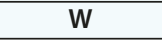 & S2020 & S2040 & S4020 & S20LS & Lime sludge & Legal threshold $\S$ \\
\hline $\mathrm{pH}$ & & 6 (0.3)bף & $5.1(0.05) a$ & $5.3(0.07) a$ & $5.6(0.4) a b$ & $5.6(0.3) a b$ & $8(0.03)$ & - \\
\hline EC & $\mathrm{dS} \mathrm{m}^{-1}$ & $0.8(0.3) a$ & $1.2(0.07) a$ & $1.1(0.1) a$ & $1.2(0.03) a$ & $1.3(0.2) a$ & $2.2(0.1)$ & - \\
\hline OC & $\%$ & $0.3(0.05) a$ & $1.7(0.3) a b$ & $3.2(0.7) b$ & $0.8(0.2) a$ & $1.1(0.8) a$ & $7(0.2)$ & - \\
\hline Total N & $\%$ & $0.01(0.00)$ a & $0.08(0.01) \mathrm{b}$ & $0.13(0.03) b$ & $0.04(0.02) a b$ & $0.06(0.04) a b$ & $0.04(0.008)$ & - \\
\hline Total S & $\%$ & $0.56(0.18)$ & & & & & $14.6(0.23)$ & - \\
\hline Total As & $\mathrm{mg} \mathrm{kg}^{-1}$ & 0\# & $0 \#$ & 0\# & $0 \#$ & $0 \#$ & $6(6)$ & 30 \\
\hline Total Cd & $\mathrm{mg} \mathrm{kg}^{-1}$ & 0\# & $0 \#$ & $0 \#$ & $0 \#$ & $0 \#$ & $0 \#$ & 5 \\
\hline Total Ca & $\mathrm{g} \mathrm{kg}^{-1}$ & $5.1(0.3) a$ & $4.3(0.4) a$ & $4.9(0.2) a$ & $4.4(0.3) a$ & $4.3(0.3) a$ & $276(74)$ & - \\
\hline Total Cr & $\mathrm{mg} \mathrm{kg}^{-1}$ & 65 (14)a & $66(4.3) a$ & $58(3.4) \mathrm{a}$ & 74 (8)a & $72(5.6) a$ & $14(2.5)$ & 250 \\
\hline Total Co & $\mathrm{mg} \mathrm{kg}^{-1}$ & $12(3.2) a$ & $7(1.0) a$ & $5.3(0.5) a$ & $6(1.0) a$ & $7(0.9) a$ & $116(24)$ & 50 \\
\hline Total Cu & $\mathrm{mg} \mathrm{kg}^{-1}$ & $88(30) a$ & $32(6) a$ & 34 (3.7)a & $36(5.1) \mathrm{a}$ & $88(60) a$ & $1158(287)$ & 100 \\
\hline Total K & $\mathrm{g} \mathrm{kg}^{-1}$ & $0.9(0.09) \mathrm{a}$ & $0.7(0.05) \mathrm{a}$ & $0.7(0.06) \mathrm{a}$ & $0.7(0.07) a$ & $0.7(0.04) \mathrm{a}$ & $0.03(0.03)$ & - \\
\hline Total Mg & $\mathrm{g} \mathrm{kg}^{-1}$ & $10(0.6) b$ & $6(0.3) a$ & $5.4(0.4) a$ & $6(0.7) a$ & $6(0.5) a$ & $15(3.7)$ & - \\
\hline Total Mn & $\mathrm{mg} \mathrm{kg}^{-1}$ & $400(50) b$ & 200 (20)a & 200 (10)a & $200(20) a$ & $200(20) a$ & $1900(400)$ & 1000 \\
\hline Total Mo & $\mathrm{mg} \mathrm{kg}^{-1}$ & 0\# & 0\# & 0\# & 0\# & 0\# & $2.3(2.3)$ & 10 \\
\hline Total Na & $\mathrm{mg} \mathrm{kg}^{-1}$ & $300(40) b$ & 200 (10)a & 200 (10)ab & 200 (10)ab & 200 (10)a & $0.1(0.04)$ & - \\
\hline Total Ni & $\mathrm{mg} \mathrm{kg}^{-1}$ & 36 (8)a & 31 (2.6)a & 26 (1.7)a & 31 (4.0)a & 31 (2.7)a & $67(14)$ & 100 \\
\hline Total P & $\mathrm{g} \mathrm{kg}^{-1}$ & $0.8(0.02) b$ & $0.6(0.04) a$ & $0.5(0.03) \mathrm{a}$ & $0.6(0.04) a$ & $0.6(0.02) a$ & $6(1.9)$ & - \\
\hline Total Pb & $\mathrm{mg} \mathrm{kg}^{-1}$ & $9(2.9)$ & 0\# & 0\# & 0\# & 0\# & $7(7)$ & 500 \\
\hline Total Se & $\mathrm{mg} \mathrm{kg}^{-1}$ & 0\# & $0 \#$ & 0\# & $0 \#$ & 0\# & $0 \#$ & 3 \\
\hline Total Sr & $\mathrm{mg} \mathrm{kg}^{-1}$ & $16(0.7) b$ & 14 (0.9)ab & $16(0.3) b$ & 13 (0.6)ab & $12(0.9) a$ & 301 (84) & - \\
\hline Total Zn & $\mathrm{mg} \mathrm{kg}^{-1}$ & $52(10) b$ & 25 (3.9)ab & 34 (5.3)ab & $18(1.6) \mathrm{a}$ & $22(7) a$ & $152(31)$ & 500 \\
\hline
\end{tabular}

† EC, electrical conductivity; OC, organic carbon.

₹ S2020, $20 \mathrm{~cm}$ layer of soil mixed with $20 \%$ peat soil; S2040, $20 \mathrm{~cm}$ layer of soil mixed with $40 \%$ peat soil; $54020,40 \mathrm{~cm}$ layer of soil mixed with $20 \%$ peat soil; S20LS, $20 \mathrm{~cm}$ layer of soil above a 20 -cm layer of lime sludge; W, direct planting in waste rocks.

§ Government of Québec (2017).

q Values are means $(\mathrm{SE})(n=3)$. Comparisons are made among treatments; and those denoted with the same lowercase letter do not significantly differ at $p=0.05$.

\# Below detection limit.

(0-45-0) placed into a slit made with a spade near the base of each cutting ( $20 \mathrm{~cm}$ from the cutting and $15 \mathrm{~cm}$ deep).

\section{Experimental Design}

Twenty experimental plots with each plot consisting of nine ramets (clonal plants) of S. miyabeana (clone Sx64) were arranged in four blocks. Each block contained each of the five soil treatments, randomly distributed, as follows: W, direct planting in waste rocks; S2020, 20-cm layer of soil mixed with peat soil (80/20 ratio in wet volume [WV]); S2040, 20-cm layer of soil mixed with peat soil (60/40 ratio WV); S4020, 40-cm layer of soil mixed with peat soil (80/20 ratio WV); S20LS, $20-\mathrm{cm}$ layer of soil above a 20 -cm layer of lime sludge) $\times$ nine cuttings. Treatments are schematized in Fig. 1. The sludge and soil layers

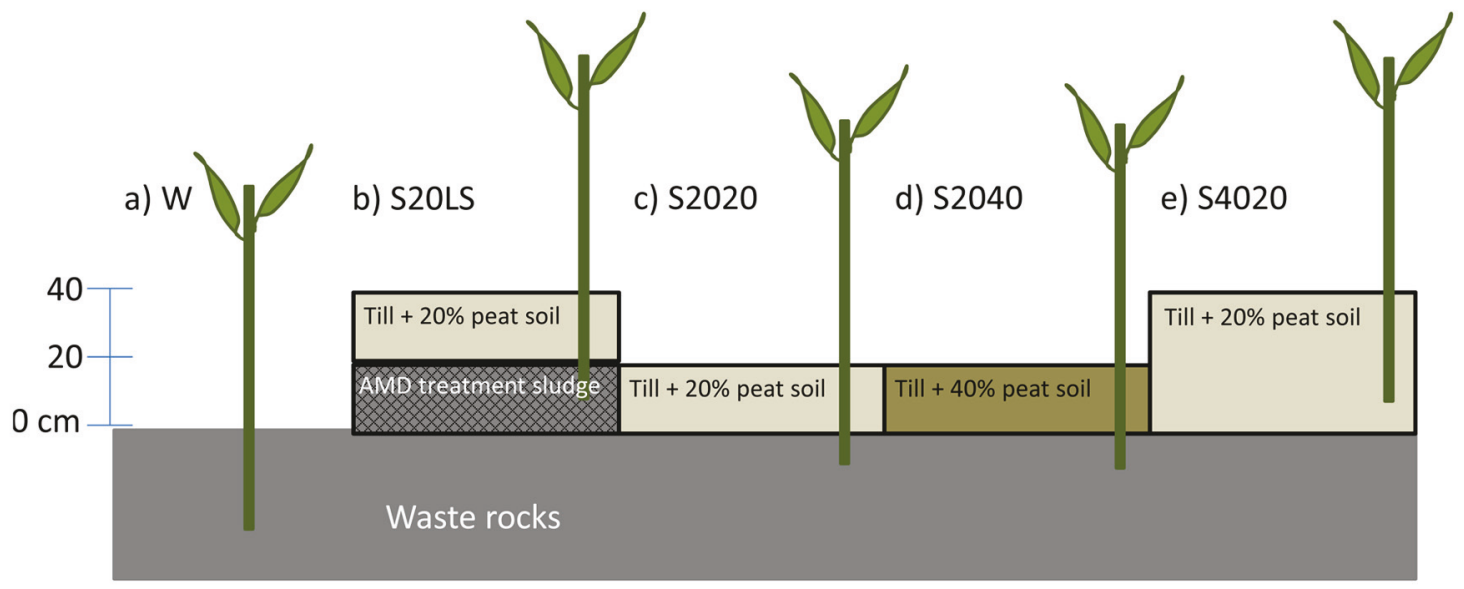

Fig. 1. Schematic representation of substrate treatments tested in the study. (a) Direct planting in waste rocks (W). (b) The 20-cm layer of soil mixed with $20 \%$ peat soil above a $20-\mathrm{cm}$ layer of lime sludge (S20LS). (c) The $20-\mathrm{cm}$ layer of soil mixed with $20 \%$ peat soil (S2020). (d) The $20-\mathrm{cm}$ layer of soil mixed with $40 \%$ peat soil (S2040). (e) The $40-\mathrm{cm}$ layer of soil mixed with $20 \%$ peat soil (S4020). AMD, acid mine drainage. 
had been applied over the waste rocks by a mechanical shovel in late May 2014. The mix between peat soil and till soil was done locally in each plot by a mechanical shovel and corresponded to $87 \%$ cover soil and $13 \%$ peat soil (S2020 and S4020) and 74\% cover soil and $26 \%$ peat soil on a dry-mass basis. Each plot of nine ramets per clone covered a $4 \mathrm{~m} \times 4 \mathrm{~m}$ area and all plots were aligned to construct an 80-m long hedge. Cuttings were spaced $1 \mathrm{~m} \times 1 \mathrm{~m}$ apart, and a 1-m buffer zone was kept free of willows at the edge of the treatment areas.

\section{Sampling, Measurements, and Analyses}

\section{Substrate}

Three random samples were taken from the lime sludge for characterization before it was placed (Table 1). Plot substrates were sampled at planting at 0 to $10 \mathrm{~cm}$ to characterize each treatment (Table 1). Each soil sample analyzed was a composite of two samples, taken in the northern and southern parts of each experimental plot $(n=20$, one sample per plot). Substrates' chemical composition was analyzed on sieved (2-mm mesh), finely ground, oven-dried samples $\left(50^{\circ} \mathrm{C}\right)$ (Lakehead University Centre for Analytical Services). Total $\mathrm{N}$ was analyzed by the Dumas combustion method (LECO CNS 2000) and OC by the thermogravimetric method (LECO-TGA). After $\mathrm{HNO}_{3}-\mathrm{HCl}$ digestion (75 and $25 \% \mathrm{v} / \mathrm{v}$, respectively), sample concentrations of total $\mathrm{P}, \mathrm{K}, \mathrm{Ca}, \mathrm{Mg}, \mathrm{Na}, \mathrm{As}, \mathrm{Cd}, \mathrm{Co}, \mathrm{Cr}, \mathrm{Cu}, \mathrm{Mo}, \mathrm{Mn}$, $\mathrm{Ni}, \mathrm{Pb}, \mathrm{Se}, \mathrm{Sr}$, and $\mathrm{Zn}$ were determined by inductively coupled plasma-atomic emission spectrometry (Vista PRO). Electrical conductivity was determined in a 1:2 water solution, and $\mathrm{pH}$ was determined in a saturated paste extract.

\section{Aboveground Development}

Survival, stem height, and basal diameter were measured at planting and at the end of each growing season in October 2014, 2015, and 2016 for each plant $(9 \times 5 \times 4=180)$. Cumulative growth increment was calculated as the difference between final (October 2016) and initial (June 2014) measurements. In August 2014 and October 2016, the second and third willow of each plot, respectively, were harvested for aboveground biomass assessment. Willows were separated into stems and leaves. Total leaf area was measured in 2014 with a LI-3100 C leaf area meter (LiCor) prior to drying. The willow parts were then oven-dried at $80^{\circ} \mathrm{C}$ for $48 \mathrm{~h}$ and weighed. Specific leaf area (total leaf area/ total leaf dry mass, $\mathrm{cm}^{2} \mathrm{mg}^{-1}$ ) was calculated.

\section{Root Development}

In September 2014 and October 2016, at the southern side of the second and the third tree of each plot, respectively, a 1 $\times 2 \mathrm{~m}$ large and 1-m-deep observation trench was dug with a mechanical shovel at $5 \mathrm{~cm}$ from the stem. Then a $75 \times 70 \mathrm{~cm}$ grid with $5 \times 5 \mathrm{~cm}$ squares was laid against the trench to study the root distribution along the substrate profile. The root occurrence (number of squares where a root was present/total number of squares $\times 100$ ) and root density (sum of the number of roots in each grid square/sum of squares' surface in $\mathrm{dm}^{-2}$ ) were noted in each trench and were compiled by substrate depth: (i) by classes of 5-cm depth, (ii) in the total soil profile $(0-70 \mathrm{~cm}$ ), (iii) at the soil surface $(0-20 \mathrm{~cm})$, and (iv) in the waste rocks from the surface (W) or under the soil layers (other treatments). The maximum depth of root occurrence $(\mathrm{cm})$ from the surface (total soil profile) and in the waste rocks was noted in each trench in October 2016.

Foliar Analyses

In August 2014 and July 2016, 10 to 20 fully mature leaves were sampled on the fifth and eighth tree of each plot and then bulked by plot $(n=20)$. In 2014, leaf samples were similarly taken from four control trees grown in the nursery. Sampled leaves were oven-dried $\left(50^{\circ} \mathrm{C}\right)$, ground, and analyzed for the same element concentrations as for soils, using the above-mentioned analytical methods. Bioaccumulation factors in leaves were calculated as foliar/substrate concentrations.

\section{Statistical Analyses}

Survival data were compared among treatments using the $\chi^{2}$ test (PROC FREQ, SAS V. 9.4, SAS Institute Inc.). Substrate and plant data were subjected to one-way ANOVA (treatment effect, PROC GLM, SAS V. 9.4). To meet the normal distribution criterion for ANOVA, some data were transformed by applying $x^{2}, \ln$, or $1 / x$ functions. If normal distribution could not be achieved, a Student's $t$ test was performed. All tested factors were fixed effects, and the block factor was considered a random effect. When effects were significant for a given variable, leastsquare means were estimated (LS MEANS statement) and post hoc Tukey tests were conducted to separate the means. Overall significance for the analyses was set at $\alpha=0.05$.

\section{Results}

\section{Aboveground Development}

The selected willow clone survived the first $3 \mathrm{yr}$ after planting when directly planted in waste rocks; however, its survival rates $(69-75 \%)$ were lower than in treatments with soil layers above the waste rocks (rates close to $100 \%$; results not shown). During the three growing seasons after planting, cumulative height and diameter increments were reduced when the willows were directly planted in waste rocks (W) compared with all other treatments $(p<0.0001)$ (Fig. 2a, b). The second, less productive treatment was willows planted in soil and lime sludge layers (S20LS), compared with willows planted in thick soil layers of $40 \mathrm{~cm}$ (S4020), which had the most productive height and diameter growth $(p<0.0001)$ (Fig. 2a, b). At the end of the first growing season, shoot biomass and total leaf area were maximized by the OC-richer soil layer (S2040, $p=0.0107$ [Fig. 2c]; $p=0.0122$ [Fig. 2d]) compared with willows planted in waste rocks without soil. After three growing seasons, however, it was the thicker soil layer (S4020) that allowed greater shoot biomass production compared with $\mathrm{W}(p=0.0316)$ (Fig. $2 \mathrm{c})$. The leaf biomass produced during the third growing season did not differ significantly among treatments; nor did the specific leaf area in the first year (results not shown).

\section{Underground Development}

After one growing season, there was no significant difference in root-system size (i.e., occurrence in the total soil profile) or density in the total soil profile among treatments (Table 2), despite differing geometries of root systems with soil depth (Fig. 3). Root occurrence was found as deep as $40 \mathrm{~cm}$ in the W treatment and in both 40-cm-thick layers (S20LS and S4020) 
a)

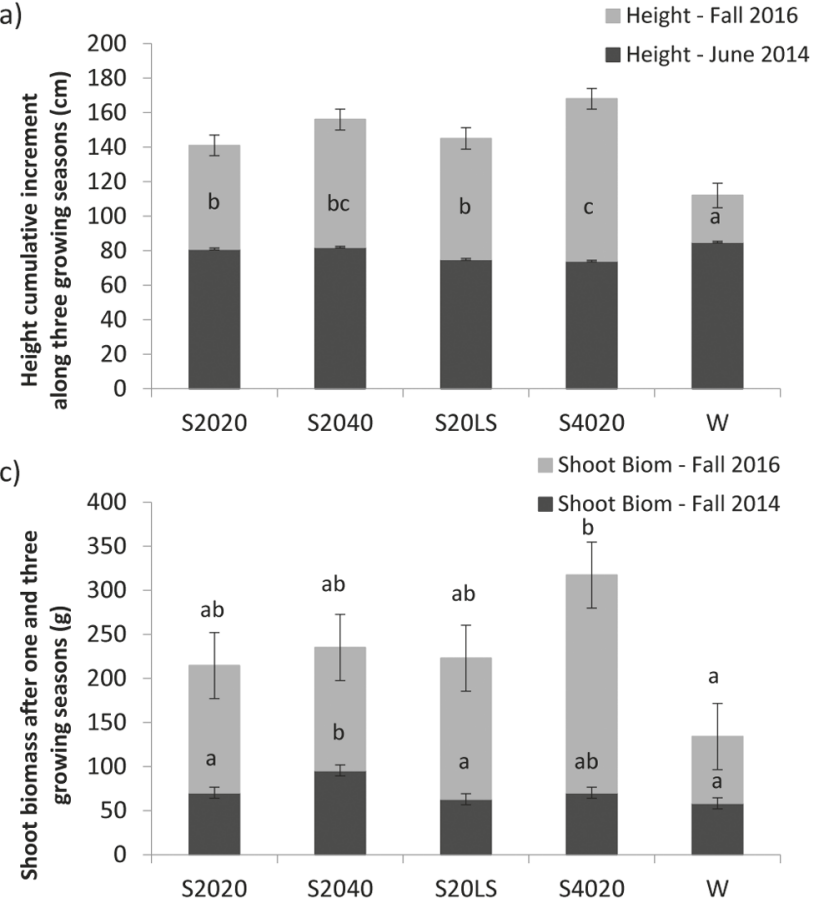

b)

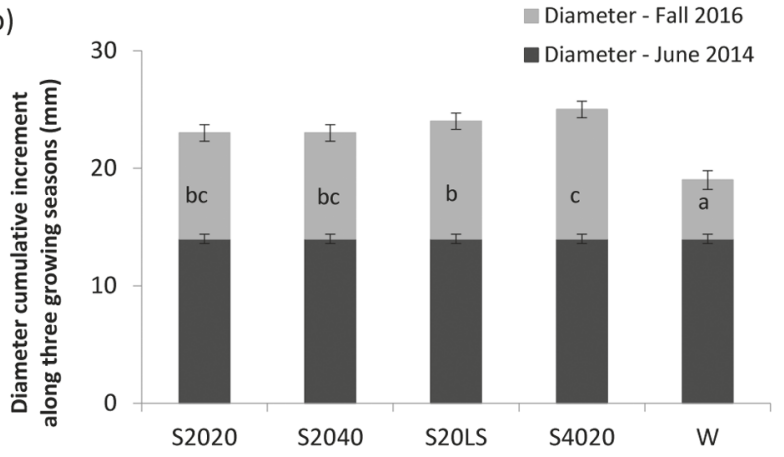

d)

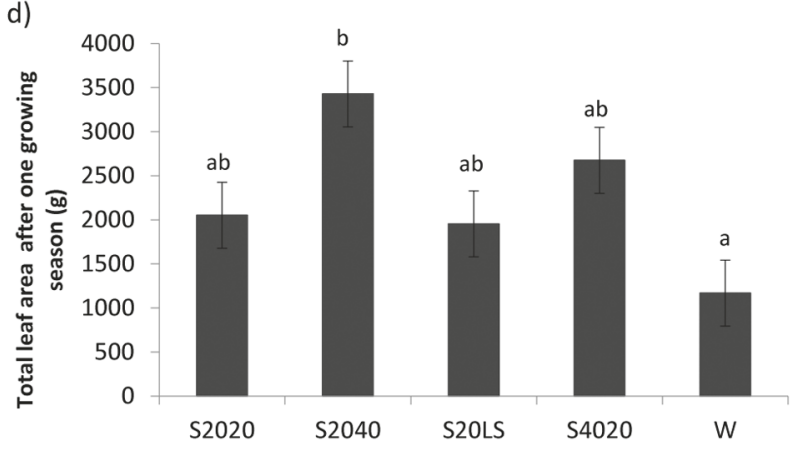

Fig. 2. Maximal height (a) and basal diameter (b) cumulative increments along the first 3 yr after planting (2014-2016), shoot biomass (c) after one and three growing seasons, and total leaf area after one growing season (d) for willows planted in the five tested treatments (S2020, 20-cm layer of soil mixed with $20 \%$ peat soil; S2040, $20-\mathrm{cm}$ layer of soil mixed with $40 \%$ peat soil; S20LS, 20 -cm layer of soil above a $20-\mathrm{cm}$ layer of lime sludge; S4020, $40-\mathrm{cm}$ layer of soil mixed with $20 \%$ peat soil; W, direct planting in waste rocks). Treatments denoted with the same lowercase letter do not significantly differ at $p=0.05$. Values are mean (SE) $(n=4)$.

after one growing season. However, roots never occurred in waste rocks under soil layers, even in thin soil layers (S2020 and S2040), with maximum rooting depth not exceeding $25 \mathrm{~cm}$. This restriction of deep root development resulted in a greater occurrence $(p=0.0007)$ and density $(p=0.0129)$ of confined roots in the first $20 \mathrm{~cm}$ of these treatments (S2020, S2040) compared with both thicker treatments (S20LS and S4020) (Table 2). This also resulted in differing root profiles: root occurrence decreased with depth in the waste rocks treatment but increased with soil depth, reaching a maximum at the soil and waste rocks interface (Fig. 3).

After three growing seasons, treatments no longer differed in the maximal depth at which roots occurred in the soil profile
(Fig. 4). Moreover, all the treatments showed similar root density along the total soil profile (Table 3). Roots had colonized the waste rocks under the soil layers in all treatments, and there was no more difference in occurrence or density of roots in the first $20 \mathrm{~cm}$ of substrate among thin- and thick-layer treatments (Table 3). Root-system size was marginally greater in the $40-\mathrm{cm}$ soil layer treatment $(S 4020 ; p=0.0634)$ compared with the control treatment without soil (W) (Fig. 4; Table 2). Root-system size in waste rocks under the S20LS treatment was lower than in S4020 ( $p=0.0062)$ (Table 2) despite a similar thickness of both treatments, which suggested a limited root development with lime sludge (Fig. 4). Finally, for both thicker $(40-\mathrm{cm})$ soil treatments (S4020 and S20LS), root density in waste rocks under the

Table 2. Root occurrence and density along different parts of the soil profile and among treatments after one (2014) and three (2016) growing seasons.

\begin{tabular}{|c|c|c|c|c|c|c|}
\hline & & \multicolumn{5}{|c|}{ Treatments $†$} \\
\hline & & W & S2020 & S2040 & S4020 & S20LS \\
\hline Root occurrence in total soil profile after one growing season & $\%$ & $14(2) a \neq$ & $12(2) \mathrm{a}$ & $17(2) \mathrm{a}$ & $16(2) a$ & $12(2) a$ \\
\hline Root occurrence in total soil profile after three growing seasons & $\%$ & $23(5) a$ & 35 (5)ab & $34(5) a b$ & $45(5) b$ & $27(5) a b$ \\
\hline Root density in total soil profile after one growing season & no. $\mathrm{dm}^{-2} \S$ & $2.9(0.6) a$ & $1.2(0.6) \mathrm{a}$ & $3.2(0.6) \mathrm{a}$ & $1.4(0.6) \mathrm{a}$ & $0.7(0.6) \mathrm{a}$ \\
\hline Root density in total soil profile after three growing seasons & no. $\mathrm{dm}^{-2}$ & $6(1) a$ & $8(1) a$ & $7(1) a$ & $10(1) a$ & $6(1) a$ \\
\hline Root occurrence in substrate surface $(0-20 \mathrm{~cm})$ after one growing season & $\%$ & $11(2) a b$ & $12(2) b$ & $17(2) b$ & $4(2) a$ & $5(2) a$ \\
\hline Root occurrence in substrate surface $(0-20 \mathrm{~cm})$ after three growing seasons & $\%$ & 57 (8)a & 74 (8)a & $88(8) a$ & $79(8) \mathrm{a}$ & $65(8) a$ \\
\hline Root density in substrate surface $(0-20 \mathrm{~cm})$ after one growing season & no. $\mathrm{dm}^{-2}$ & 9 (2)ab & $6(2) a b$ & $11(2) b$ & $1(2) \mathrm{a}$ & $1(2) \mathrm{a}$ \\
\hline Root density in substrate surface $(0-20 \mathrm{~cm})$ after three growing seasons & no. $\mathrm{dm}^{-2}$ & $16(3) \mathrm{a}$ & $18(3) \mathrm{a}$ & $19(3) \mathrm{a}$ & $17(3) \mathrm{a}$ & $15(3) \mathrm{a}$ \\
\hline Root occurrence in waste rocks after three growing seasons & $\%$ & $61(6) a b$ & 44 (6)ab & $37(6) a b$ & $56(6) b$ & $24(6) a$ \\
\hline Root density in waste rocks after three growing seasons & no. $\mathrm{dm}^{-2}$ & $3.0(0.4) b$ & $1.7(0.4) \mathrm{ab}$ & $1.3(0.4) \mathrm{a}$ & $2.0(0.4) \mathrm{ab}$ & $0.9(0.4) \mathrm{a}$ \\
\hline
\end{tabular}

+ S2020, 20-cm layer of soil mixed with $20 \%$ peat soil; S2040, 20-cm layer of soil mixed with $40 \%$ peat soil; $54020,40-\mathrm{cm}$ layer of soil mixed with $20 \%$ peat soil; S2OLS, 20-cm layer of soil above a $20-\mathrm{cm}$ layer of lime sludge; W, direct planting in waste rocks.

$\ddagger$ Values are means $(\mathrm{SE})(n=4)$. Within a variable, means that do not differ among treatments at the 0.05 level are noted with the same letter $(\mathrm{a}<\mathrm{b})$. $\S$ Number of grid squares where roots are present/total of squares $\times 100$. 

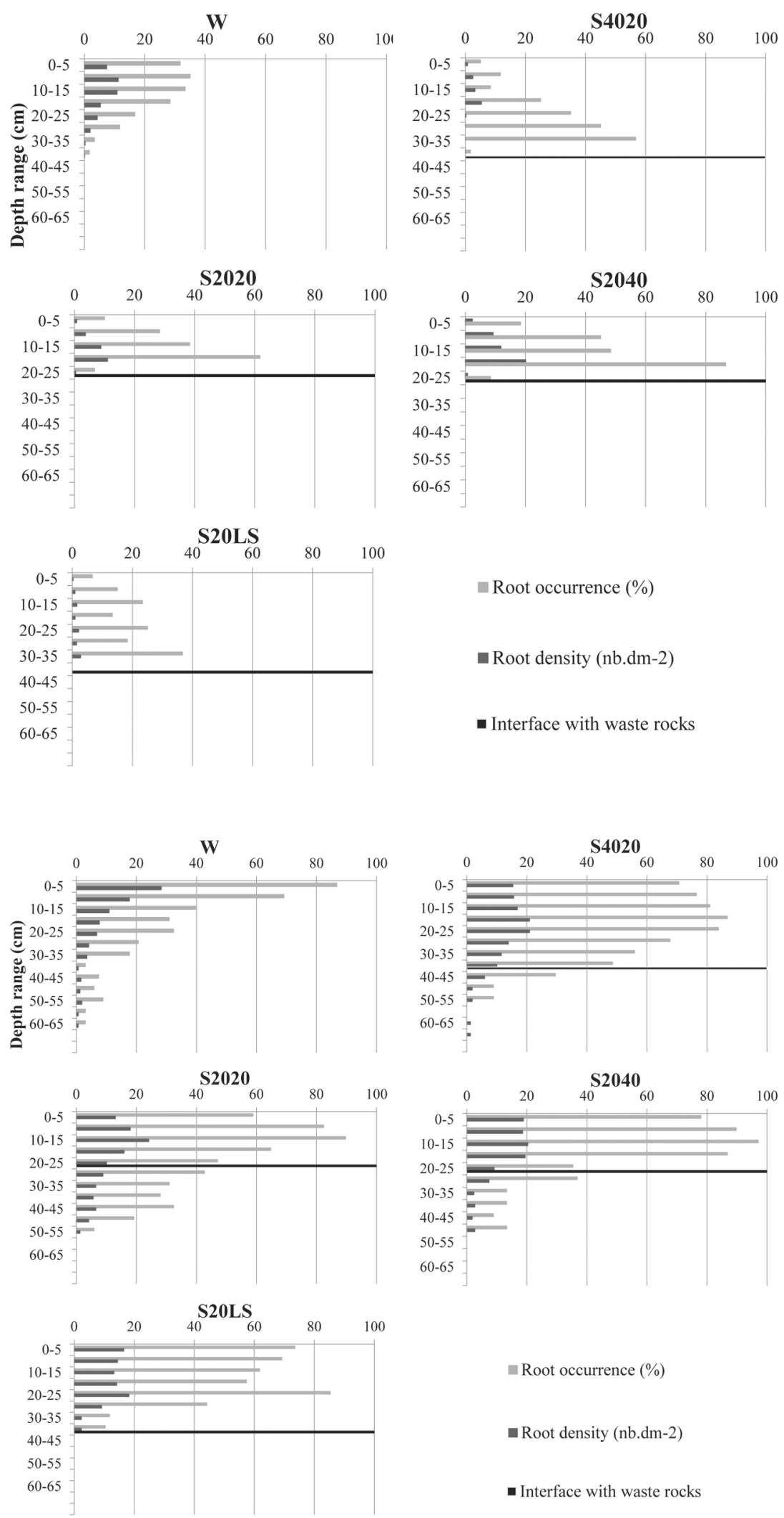

Root occurrence $(\%)$

- Root density (nb.dm-2)

- Interface with waste rocks

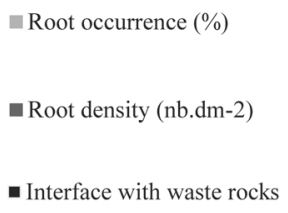

Fig. 3. Willow root profiles (root occurrence in $\%$ and density in number of roots $\mathrm{dm}^{-2}$ ) along a $75 \times 70 \mathrm{~cm}$ observation trench among the five tested treatments (S2020, 20-cm layer of soil mixed with $20 \%$ peat soil; S2040, $20-\mathrm{cm}$ layer of soil mixed with $40 \%$ peat soil; S2OLS, $20-\mathrm{cm}$ layer of soil above a $20-\mathrm{cm}$ layer of lime sludge; $\mathrm{S} 4020,40-\mathrm{cm}$ layer of soil mixed with $20 \%$ peat soil; $\mathrm{W}$, direct planting in waste rocks) at the end of the first growing season after planting (2014). Values are means $(n=4)$.
Fig. 4. Willow root profiles (root occurrence in $\%$ and density in number of roots $\mathrm{dm}^{-2}$ ) along a $75 \times 70 \mathrm{~cm}$ observation trench among the five tested treatments (S2020, 20-cm layer of soil mixed with $20 \%$ peat soil; S2040, $20-\mathrm{cm}$ layer of soil mixed with $40 \%$ peat soil; S20LS, $20-\mathrm{cm}$ layer of soil above a $20-\mathrm{cm}$ layer of lime sludge; S4020, 40-cm layer of soil mixed with $20 \%$ peat soil; $\mathrm{W}$, direct planting in waste rocks) at the end of the third growing season after planting (2016). Values are means $(n=4)$. soil layers was lower than in waste rocks at the surface in the W treatment $(p=0.013)$ (Table 2).

\section{Element Concentrations of Substrates and Foliage}

Mixing peat soil with till decreased the mixture's $\mathrm{pH}$ and increased its OC concentration compared with the waste rocks treatment (Table 1), but differences were not significant with every other soil treatment, probably due to the mixtures' heterogeneity. Mixing till with peat soil did not significantly affect the mixtures' EC, which remained similar to that of the W treatment, but increased total $\mathrm{N}$, whereas waste rocks showed greater total $\mathrm{P}$ and $\mathrm{Zn}$ concentrations than soils (Table 1). Lime sludge showed greater OC concentrations, electrical conductivity, and $\mathrm{pH}$ than waste rocks and till (Table 1). 
In the first growing season, the willows' foliage $\mathrm{N}$ concentration in the W treatment was two times lower than in other treatments, but this concentration did not differ from the unfertilized nursery-grown control; in the thicker soil treatment (S4020), foliage had the greatest $\mathrm{N}$ concentration (Table 3 ). During the third growing season, $\mathrm{N}$ foliar concentrations had decreased in all treatments to similar levels. Foliar concentrations of $\mathrm{P}$ were similar among the treatments for both years (Table 3) and were lower than the concentrations in the unfertilized nursery-grown control $(\times 1 / 2)$. Finally, willows grown at the mine site had greater foliar $\mathrm{Na}$ (6-10 times greater) compared with the nursery control the first year (2014), and these concentrations doubled in all treatments the third year after planting (2016) to reach around $100 \mathrm{ppm}$.

Table 3. Willow foliar concentrations of chemical elements and bioconcentration factors (i.e., foliar/substrate concentrations) the first (August 2014) and third growing season (July 2016) among treatments. Values are mean (SE) $(n=4)$. All values are expressed on a dry matter basis.

\begin{tabular}{|c|c|c|c|c|c|c|c|}
\hline \multirow{2}{*}{ Element } & \multirow{2}{*}{ Unit } & \multicolumn{5}{|c|}{ Treatments $\dagger$} & \multirow{2}{*}{ Control } \\
\hline & & $\mathbf{W}$ & S2020 & 2 & S4020 & S20LS & \\
\hline \multicolumn{8}{|c|}{2014 (first growing season) } \\
\hline $\mathrm{N}$ & $\%$ & $1.5(0.2) a \neq$ & $3.1(0.1) b$ & $2.8(0.1) \mathrm{b}$ & $3.4(0.1) c$ & $3.0(0.1) b$ & $2.2(0.3) a b$ \\
\hline As & $\mathrm{mg} \mathrm{kg}^{-1}$ & 0 वा & 0ๆ & 0ๆ & 0ๆ & 0ๆ & 0ๆ \\
\hline $\mathrm{Cd}$ & $\mathrm{mg} \mathrm{kg}^{-1}$ & $0.7(0.5) a$ & $2.1(0.7) \mathrm{a}$ & $6.1(1.0) b$ & 3.9 (1.4)ab & $0(0) a$ & $0(0) a$ \\
\hline $\mathrm{Ca}$ & $\mathrm{g} \mathrm{kg}^{-1}$ & $25(1.5) b$ & $14(0.7) a$ & $18(0.6) a$ & 17 (1.9)a & $18(0.8) a$ & $15(1.4) \mathrm{a}$ \\
\hline $\mathrm{Cr}$ & $\mathrm{mg} \mathrm{kg}^{-1}$ & $5.1(5.1)$ & 0ๆ & 0ி & 0ๆ & 0ๆ & 0ๆ \\
\hline Co & $\mathrm{mg} \mathrm{kg}^{-1}$ & $1.0(0.6) \mathrm{ab}$ & $1.1(0.4) \mathrm{ab}$ & $0.3(0.3) a$ & $0.5(0.5) a$ & $1.9(0.2) b$ & $3.5(1.2) b$ \\
\hline $\mathrm{Cu}$ & $\mathrm{mg} \mathrm{kg}^{-1}$ & $6.4(0.6) a b$ & $8.6(0.4) b c$ & $7.8(0.4) \mathrm{bc}$ & $9.1(0.6) \mathrm{c}$ & $8.7(0.4) b c$ & $4.3(0.7) a$ \\
\hline K & $\mathrm{g} \mathrm{kg}^{-1}$ & $12(0.8) \mathrm{a}$ & $19(1.3) \mathrm{b}$ & $15(0.4) a b$ & 17 (2.2)ab & $13(1.4) \mathrm{a}$ & 15 (0.9)ab \\
\hline $\mathrm{Mg}$ & $\mathrm{g} \mathrm{kg}^{-1}$ & $2.7(0.3) a$ & $3.5(0.4) \mathrm{ab}$ & $3.0(0.2) \mathrm{a}$ & $3.2(0.2) \mathrm{a}$ & $5.6(0.4) b$ & $3.4(0.7) a$ \\
\hline $\mathrm{Mn}$ & $\mathrm{mg} \mathrm{kg}^{-1}$ & $280(36) b$ & 161 (11)a & 148 (18)a & $175(26) a b$ & $123(6) a$ & $111(20) a$ \\
\hline Mo & $\mathrm{mg} \mathrm{kg}^{-1}$ & 0 0ी & 0ๆ & 0ๆ & 0ๆ & 0ๆ & 0ๆ \\
\hline $\mathrm{Na}$ & $\mathrm{mg} \mathrm{kg}^{-1}$ & $52(6) \mathrm{b}$ & $32(5) b$ & $43(5) \mathrm{b}$ & $49(8) \mathrm{b}$ & $45(4) b$ & $5(3) a$ \\
\hline $\mathrm{Ni}$ & $\mathrm{mg} \mathrm{kg}^{-1}$ & $2.4(2.4) a$ & $10.3(2.5) b$ & $0(0) a$ & 4.9 (2.9)ab & $0(0) \mathrm{a}$ & $10.6(2.2) b$ \\
\hline$P$ & $\mathrm{~g} \mathrm{~kg}^{-1}$ & $2.1(0.2) a$ & $2.1(0.4) a$ & $1.6(0.03) a$ & $2.0(0.1) \mathrm{a}$ & $2.2(0.2) a$ & $5.4(0.2) b$ \\
\hline $\mathrm{Pb}$ & $\mathrm{mg} \mathrm{kg}^{-1}$ & 0ๆ & 0ๆ & 0ी & 0ๆ & 0ๆ & 0ी \\
\hline $\mathrm{Se}$ & $\mathrm{mg} \mathrm{kg}^{-1}$ & 0ๆ & 0ๆ & 0ी & 0थ & 0ๆ & 0ी \\
\hline $\mathrm{Sr}$ & $\mathrm{mg} \mathrm{kg}^{-1}$ & $92(9) b$ & 34 (3)a & $51(2) a$ & 49 (12)a & 57 (3)a & $23(2) a$ \\
\hline $\mathrm{Zn}$ & $\mathrm{mg} \mathrm{kg}^{-1}$ & $145(25) a b$ & 106 (13)ab & $244(36) b$ & $257(98) b$ & 102 (8)ab & $76(5) a$ \\
\hline Zn BCF§ & & $3.1(4.0) a$ & $4.5(4.0) \mathrm{a}$ & $11.6(4.0) a$ & $10.2(4.0) a$ & $8.9(4.0) a$ & \\
\hline Sr BCF & & $5.9(0.5) \mathrm{c}$ & $2.5(0.5) \mathrm{a}$ & $3.9(0.5) a b$ & $3.4(0.5) a b$ & $4.7(0.5) b c$ & \\
\hline \multicolumn{8}{|c|}{2016 (third growing season) } \\
\hline $\mathrm{N}$ & $\%$ & $1.2(0.05) \mathrm{a}$ & $1.2(0.05) \mathrm{a}$ & $1.2(0.05) a$ & $1.2(0.05) \mathrm{a}$ & $1.2(0.05) \mathrm{a}$ & \\
\hline As & $\mathrm{mg} \mathrm{kg}^{-1}$ & 0 ๆ & 0 वी & 0ी & 0 0ी & 0ி & \\
\hline $\mathrm{Cd}$ & $\mathrm{mg} \mathrm{kg}^{-1}$ & $3.0(1.0) a$ & $5.1(1.0) a b$ & $8.1(1.0) b$ & $8.5(1.0) b$ & $0.5(1.0) a$ & \\
\hline $\mathrm{Ca}$ & $\mathrm{g} \mathrm{kg}^{-1}$ & $24(1) b$ & $24(1) b$ & $22(1) b$ & $22(1) b$ & $19(1) \mathrm{a}$ & \\
\hline $\mathrm{Cr}$ & $\mathrm{mg} \mathrm{kg}^{-1}$ & $4.7(1.2) a$ & $0.9(1.2) \mathrm{a}$ & $0.9(1.2) a$ & $0.9(1.2) \mathrm{a}$ & $0.8(1.2) a$ & \\
\hline Co & $\mathrm{mg} \mathrm{kg}^{-1}$ & $1.8(0.3) \mathrm{a}$ & $2.0(0.3) \mathrm{a}$ & $1.4(0.3) \mathrm{a}$ & $1.7(0.3) \mathrm{a}$ & $4.3(0.3) b$ & \\
\hline $\mathrm{Cu}$ & $\mathrm{mg} \mathrm{kg}^{-1}$ & $6.2(0.3) a$ & $6.5(0.3) a$ & $6.5(0.3) a$ & $6.5(0.3) a$ & $6.4(0.3) a$ & \\
\hline K & $\mathrm{g} \mathrm{kg}^{-1}$ & $17(1) c$ & $14(1) b$ & $14(1) b$ & $14(1) b$ & $10(1) a$ & \\
\hline $\mathrm{Mg}$ & $\mathrm{g} \mathrm{kg}^{-1}$ & $1.0(0.2) a$ & $1.4(0.2) a$ & $1.3(0.2) a$ & $1.7(0.2) a$ & $4.7(0.2) b$ & \\
\hline $\mathrm{Mn}$ & $\mathrm{mg} \mathrm{kg}^{-1}$ & $140(20) a$ & $233(20) c$ & $171(20) b$ & $174(20) b$ & $108(20) a$ & \\
\hline Mo & $\mathrm{mg} \mathrm{kg}^{-1}$ & & 0ๆ & 0ๆ & 0ๆ & 0ๆ & \\
\hline $\mathrm{Na}$ & $\mathrm{mg} \mathrm{kg}^{-1}$ & 94 (6)a & 109 (6)a & $98(6) a$ & 95 (6)a & $100(6) a$ & \\
\hline $\mathrm{Ni}$ & $\mathrm{mg} \mathrm{kg}^{-1}$ & 0ๆ & 0ๆ & 0 ๆ & 0ๆ & 0ๆ & \\
\hline$P$ & $\mathrm{~g} \mathrm{~kg}^{-1}$ & $2.6(0.2) a$ & $2.6(0.2) a$ & $2.0(0.2) a$ & $2.2(0.2) a$ & $2.6(0.2) a$ & \\
\hline $\mathrm{Pb}$ & $\mathrm{mg} \mathrm{kg}^{-1}$ & 0ๆ & 0ๆ & 0ๆ & 0ๆ & 0ๆ & \\
\hline $\mathrm{Se}$ & $\mathrm{mg} \mathrm{kg}^{-1}$ & 09 & 0ๆ & 0 ๆ & 0थ & 0ๆ & \\
\hline $\mathrm{Sr}$ & $\mathrm{mg} \mathrm{kg}^{-1}$ & $49(3) b$ & 44 (3)a & $46(3) a$ & 37 (3)a & 38 (3)a & \\
\hline $\mathrm{Zn}$ & $\mathrm{mg} \mathrm{kg}^{-1}$ & 237 (37)a & 297 (37)a & 335 (37)a & 324 (37)a & 194 (37)a & \\
\hline $\mathrm{Zn} \mathrm{BCF}$ & & $5.2(4.0) a$ & $12.1(4.0) a$ & $16.1(4.0) a$ & $13.0(4.0) a$ & $16.6(4.0) a$ & \\
\hline $\mathrm{Sr} \mathrm{BCF}$ & & $3.1(0.5) a$ & $3.2(0.5) a$ & $3.4(0.5) a$ & $2.5(0.5) a$ & $3.1(0.5) a$ & \\
\hline
\end{tabular}

+ S2020, 20-cm layer of soil mixed with 20\% peat soil; S2040, 20-cm layer of soil mixed with $40 \%$ peat soil; $54020,40-\mathrm{cm}$ layer of soil mixed with $20 \%$ peat soil; S20LS, 20 -cm layer of soil above a $20-\mathrm{cm}$ layer of lime sludge; $\mathrm{W}$, direct planting in waste rocks.

₹ Treatments denoted with the same lowercase letter do not significantly differ at $p=0.05$.

$\S$ Bioconcentration factor

I Below detection limit. 
Willows grown in the treatment combining a soil layer with an underlying lime sludge layer (S20LS) showed slightly lower foliar $\mathrm{K}$ and $\mathrm{Ca}$ and greater $\mathrm{Mg}$ compared with other treatments. Despite greater trace metal concentrations in lime sludge for Co, $\mathrm{Cu}, \mathrm{Mn}, \mathrm{Mo}, \mathrm{Ni}, \mathrm{Pb}, \mathrm{Sr}$, and $\mathrm{Zn}$ than in soils and waste rocks (Table 1), willows grown in the S20LS treatment did not accumulate any metal (except Co but at low concentration) compared with other treatments (Table 3), either at the short (1-yr) or the medium (3-yr) term after planting. In fact, S20LS treatment restricted the accumulation of $\mathrm{Mn}$ and $\mathrm{Cd}$ compared with other treatments (Table 3).

Willow bioconcentration factors in foliage were below 1 for all investigated trace metals, except $\mathrm{Zn}$ and $\mathrm{Sr}$ (Table 3). The $\mathrm{Cd}$ bioaccumulation factor could not be calculated because its concentration was below detection limits $(1.25 \mathrm{ppm})$ in all substrates (Table 1). No foliar accumulation occurred in leaves of any treatment for $\mathrm{Cu}, \mathrm{Mo}, \mathrm{Ni}, \mathrm{Pb}$, or $\mathrm{Se}$.

Willow foliage accumulated Cd in soil-layer treatments compared with W, in particular in S2040 for the first and third years and in $\$ 4020$ the third year after planting, and this accumulation increased with time even if $\mathrm{Cd}$ was undetectable in substrates. Conversely, $\mathrm{Cr}$ was present in the foliage of willows directly planted in waste rocks, whereas it was below detection limit (0.6 ppm) the first year or very low the third year after planting for other treatments. The W treatment had greater Mn concentrations in the foliage the first year compared with other treatments. However, Mn concentrations in foliage had decreased by the third year in the W treatment, appearing lower than in other treatments except S20LS. The W treatment also showed greater $\mathrm{Sr}$ concentrations in foliage for both years compared with other treatments, but the Sr bioaccumulation factor was greater in W than in other treatments only the first year after planting.

Finally, $\mathrm{Zn}$ concentrations were greater in the foliage of all treatments at the mine site compared with the nursery-grown control the first year, especially in S2040 and S4020 treatments, and these concentrations increased the third year after planting in all treatments. The $\mathrm{Zn}$ bioaccumulation factor in willow leaves varied from 3 to 17 (Table 3 ).

\section{Discussion}

\section{Root Development in Waste Rocks Alone Treatment}

Salix miyabeana survived and grew when directly planted in the waste rocks, confirming that willows are a pioneer woody species well adapted to colonizing mine wastes. Contrary to our first hypothesis, willows were indeed able to alleviate planting stress by growing roots directly in the waste rocks. Moreover, root development was extensive: roots reached $40 \mathrm{~cm}$ deep into the waste rocks as early as the first growing season and $65 \mathrm{~cm}$ at the end of the third growing season. Waste rocks were extracted from a shale bedrock, producing fine particles by physical alteration after water adsorption. These fine particles may provide a more favorable substrate for root growth compared with waste rocks extracted from hard, alteration-resistant lithology. Aerial growth of willows appeared restricted when they were planted into waste rocks in the first year, concomitant with reduced foliar $\mathrm{N}$ concentrations. Because low $\mathrm{OC}$ substrates such as mine wastes have decreased nutrient retention (Tordoff et al., 2000), N provided by fertilization at planting may have been lost in this treatment, even if root length density and root weight density were greater compared with thicker soil treatment. Moreover, the elevated hydraulic conductivity of the waste rocks could have promoted leaching losses of fertilizer beyond the willows' root zone.

\section{Root Development in Soil Layer Treatments}

The use of soil layers improved willow survival and aboveground development, especially in the thick soil layer treatment ( 40 $\mathrm{cm})$. In the short term, willow root development was restricted in waste rocks under all soil layers. The use of thicker and richer soils probably allowed root access to more resources, especially $\mathrm{N}$ and water. Indeed, root growth is known to follow patterns of water and nutrient availability in the substrate (Stokes et al., 2009), which may explain their preferential growth in soil compared with waste. In consequence, the thicker the soil layer, the greater the foliar $\mathrm{N}$ concentration and the growth in height and diameter, whereas the more OC-rich the soil layer, the greater the aerial biomass and total leaf area. Increased aboveground biomass associated with the OC-richer layer could have resulted in an $\mathrm{N}$ dilution effect in leaves. By the third year after planting, no difference in aboveground growth was detectable between thin layers, whether they were enriched with organic matter or not. This means that the positive effect of organic matter enrichment on willow productivity was short lived.

In the longer term (third year after planting), and contrary to our second hypothesis, willow roots had efficiently colonized waste rocks under all soil-layer treatments. No measurable difference in maximal depth of root occurrence in waste rocks was related to soil-layer thickness, contrary to Wagner et al. (2007). Thus, willow roots have the ability to quickly overcome the restriction of root development in underlying waste rocks when soil layers are used. However, the size of the root system was maximized in the thicker soil layer treatment compared with all other treatments, concomitant with a greater aboveground biomass and growth. The greater the size of the root system, the greater its probability of reaching heterogeneously distributed resources in the substrate (Rajaniemi, 2007). Larchevêque et al. (2015) found similar results above waste rocks of another gold mine, where thicker soil layers increased the $\mathrm{N}$ nutrition of trees as well as their aboveground development. These above- and belowground growth results demonstrate that, for the selected willow clone, a having larger root system is the most efficient way to support sustained productivity in the medium term. In soil layers thinner than $40 \mathrm{~cm}$ (even those improved through organic matter enrichment), the restricted deep development of roots during the first year resulted in delayed willow productivity the following years compared with a thicker soil layer. Because willow root depth in waste rocks alone reached no more than $40 \mathrm{~cm}$ deep the first year after planting, a $40-\mathrm{cm}$ thickness of the soil layer may be optimal for not limiting root-system size of the selected clone.

\section{Trace Element Accumulation in Foliage}

The tested S. miyabeana clone accumulated $\mathrm{Zn}$ and $\mathrm{Cd}$ in its leaves, in keeping with its previously demonstrated phytoextraction potential of both metals (Zhivotosky et al., 2011), especially in thicker and OC-richer soils. Acidification of the soil due to mixing with peat may have been partially responsible for an increase in $\mathrm{Zn}$ and Cd availability to roots (Prasad and Strzalka, 
2002). Concentrations of both metals increased over time, reaching concentrations that may be phytotoxic (100-400 ppm for $\mathrm{Zn}$ and 5-30 ppm for Cd) (Kabata-Pendias and Pendias, 2001), but accumulation concentrations remained far lower than those required for $\mathrm{Zn}$ phytoextraction (Mahar et al., 2016). Because both treatments with the greatest concentrations in $\mathrm{Cd}$ and $\mathrm{Zn}$ in foliage were also the most productive for aboveground growth, S. miyabeana Sx64 may tolerate these elevated concentrations of both metals, at least in the short term. Moreover, because roots had developed in the waste rocks under all soil layers the third year after planting, the use of a thicker soil layer did not reduce trace metal accumulation compared with thinner soil layers, contrary to our third hypothesis.

On waste rocks, the exclusion ability of the tested willow regarding $\mathrm{Cr}, \mathrm{Mn}$, and $\mathrm{Sr}$ in foliage appeared limited compared with treatments with soil layers. However, the foliar concentrations of these metals remained low overall and decreased with time for $\mathrm{Mn}$ and $\mathrm{Sr}$ to finally become similar to those found in soil-layer treatments. Metal accumulation in the willows should be followed over the longer term because (i) the acid-generating properties of the waste rocks can persist for decades, and $\mathrm{Cr}$ accumulation could thus continue to increase in foliage because its availability increases at low $\mathrm{pH}$ (Kabata-Pendias and Pendias, 2001; Prasad and Strzalka, 2002); (ii) Zn and Cd accumulation in foliage could also be sensitive to acidification of the substrate and may become phytotoxic; and (iii) the production of a $\mathrm{Zn}$ - and Cd-contaminated litter by willows could decrease soil decomposers' activity in the organic horizon (Jordan and Lechevalier, 1975) over time and could slow down organic matter recycling (Coughtrey et al., 1979) until tolerant soil organisms develop.

\section{Combination of a Lime Sludge and a Soil Layer}

The presence of alkaline AMD treatment sludge under the soil decreased willow aboveground growth concomitant with a reduced deep root development in waste rocks compared with the soil layer with the same thickness. The alkaline $\mathrm{pH}$ and greater electrical conductivity of the sludge may have restricted root growth by increasing salinity exposure, even if willows are reported to be tolerant to greater salinity levels $\left(5 \mathrm{dS} \mathrm{cm} \mathrm{cm}^{-1}\right)$ (Hangs et al., 2011) than those found in the sludge $\left(2.2 \mathrm{dS} \mathrm{m}^{-1}\right)$. Moreover, due to their fine grain size (Demers et al., 2015), AMD treatment sludges easily remain water saturated, which could create anoxic conditions and restrict root growth.

Sludge presence also reduced the accumulation of $\mathrm{Mn}$ and $\mathrm{Cd}$ in willow foliage compared to all other treatments, probably through a pH increase (Das et al., 1997; Markert et al., 2000), which confirms our fourth hypothesis. However, greater total Zn concentrations (around $\times 3$ ) in lime sludge compared with soils could also have participated in decreasing Cd availability to willows (Chaney et al., 2009; Kukier et al., 2010). Whether the efficient Mn barrier effect is associated with sludge alkalinity or reduced contact of willow roots with waste rocks that are richer in this element is not clear. Despite its mitigating effect on willow growth, combining sludge-barrier use with $S$. miyabeana planting may be particularly useful on Cd-contaminated waste rocks or soils to reduce the $\mathrm{Cd}$ phytoaccumulation potential in foliage over time. The use of alkaline AMD treatment sludge with an increased thickness of the overlying soil layer may alleviate above- and belowground growth restrictions while allowing the reuse of a mine waste for site revegetation.

\section{Conclusion}

In conclusion, $S$. miyabeana $\mathrm{Sx} 64$ appeared well adapted to planting on acid-generating waste rocks. It was able to grow roots extensively in waste rocks, which limited planting stress, even if root development was delayed in waste rocks when soil layers were used. The use of thicker soil layers was more effective than OC-richer soil layers to maximize willow above- and belowground productivity over time, and a 40-cm thickness should avoid limitations in root-system size the first year after planting. Our experiment confirmed the ability of this willow clone to accumulate $\mathrm{Cd}$ and $\mathrm{Zn}$ in its foliage, especially when soil layers were used. This accumulation, even if well tolerated initially by the willows, could slow down litter decomposition processes and organic matter cycling, which is the starting point of ecosystem development. Moreover, this willow clone's use for phytostabilization may be limited even if it can develop extensive root systems in the mine Technosol. Both $\mathrm{Cd}$ and $\mathrm{Zn}$ concentrations increased into foliage over time, whereas this willow clone seemed able to reduce the translocation of $\mathrm{Mn}$ and $\mathrm{Sr}$ toward the foliage over time. Cadmium and $\mathrm{Zn}$ phytotoxicity could occur later if they continue to accumulate in leaves and should be kept under surveillance. Finally, an alkaline AMD treatment sludge combined with a soil layer could be used as a barrier to $\mathrm{Cd}$ and $\mathrm{Mn}$ accumulation in willows but at the cost of reduced aboveand belowground productivity if the soil layer thickness is too low. Further work is thus needed to improve the reuse of this sludge in substrates used for revegetation.

\section{Acknowledgments}

This work was supported by the Natural Sciences and Engineering Research Council of Canada under Discovery grant RGPIN-2015-04583; by IAMGOLD Corporation, Westwood mine; and by the Research Institute on Mines and Environment for fieldwork and student training. The authors thank A. Jobin, H. Jobin, and M. Dallaire for assistance in fieldwork; J. Muzak for editing assistance; and the associate editor and editor for their relevant comments that helped to improve the paper. This work integrates the work done by A. Dallaire for her Master nonthesis report.

\section{References}

Agriculture and Agri-Food Canada. 2010. The Canadian system of soil classification, 3rd ed. http://sis.agr.gc.ca/cansis/taxa/cssc3/index.html (accessed 24 Mar. 2017).

Aubertin, M., B. Bussière, and L. Bernier. 2002. Environnement et gestion des rejets miniers. Presses internationales Polytechnique, Montreal, QC, Canada.

Baker, A.J.M., and P.L. Walker. 1989. Physiological responses of plants to heavy metals and the quantification of tolerance and toxicity. Chem. Spec. Bioavail. 1(1):7-17. doi:10.1080/09542299.1989.11083102

Boyter, M.J., J.E. Brummer, and W.C. Leininger. 2009. Growth and metal accumulation of Geyer and mountain willow grown in topsoil versus amended mine tailings. Water Air Soil Pollut. 198:17-29. doi:10.1007/ s11270-008-9822-9

Chaney, R.L., C.E. Green, H.A. Ajwa, and R.F. Smith. 2009. Zinc fertilization plus liming to reduce cadmium uptake by romaine lettuce on $\mathrm{Cd}$-mineralized lockwood soil. The Proceedings of the International Plant Nutrition Colloquium XVI. Dep. of Plant Sciences, Univ. of California, Davis.

Chesworth, W., and O. Spaargaren. 2008. Technosols. In: W. Chesworth, editor, Encyclopedia of soil science. Encyclopedia of Earth Sciences Series. Springer, New York. p. 765-766.

Comas, L.H., S.R. Becker, V.M.V. Cruz, P.F. Byrne, and D.A. Dierig. 2013. Root traits contributing to plant productivity under drought. Front. Plant Sci. $4(442): 1-16$. 
Cooke, J.A., and M.S. Johnson. 2002. Ecological restoration of land with particular reference to the mining of metals and industrial minerals: A review of theory and practice. Environ. Rev. 10:41-71. doi:10.1139/a01-014

Coughtrey, P.J., C.H. Jones, M.H. Martin, and S.W. Shales. 1979. Litter accumulation in woodlands contaminated by $\mathrm{Pb}, \mathrm{Zn}, \mathrm{Cd}$ and $\mathrm{Cu}$. Oecologia 39:51-60. doi:10.1007/BF00345996

Das, P., S. Samantaray, and G.R. Rout. 1997. Studies on cadmium toxicity in plants: A review. Environ. Pollut. 98(1):29-36. doi:10.1016/ S0269-7491(97)00110-3

Demers, I., M. Bouda, M. Mbonimpa, M. Benzaazoua, D. Bois, and M. Gagnon. 2015. Valorisation of acid mine drainage treatment sludge as remediation component to control acid generation from mine wastes, part 1: Material characterization and laboratory kinetic testing. Miner. Eng. 76:109-116. doi:10.1016/j.mineng.2014.10.015

Emerson, P., J. Skousen, and P. Ziemkiewicz. 2009. Survival and growth of hardwoods in brown versus gray sandstone on a surface mine in West Virginia. J. Environ. Qual. 38:1821-1829. doi:10.2134/jeq2008.0479

Gélinas, P., R. Lefebvre, M. Choquette, D. Isabel, J. Locat, and R. Guay. 1994. Monitoring and modelling of acid mine drainage from waste rock dumps: La Mine Doyon case study. MEND Report 1.14.2 g. City Univ., SainteFoy, QC.

Government of Canada. 2017. National climate archives. http://climate.weather.gc.ca/ (accessed 24 Mar. 2017).

Government of Quebec. 2017. Annexe I: Règlement sur la protection et la réhabilitation des terrains, LQE Chapitre Q2 r.37. www2.publicationsduquebec. gouv.qc.ca/dynamicSearch/telecharge.php?type $=3 \&$ file $=/ \mathrm{Q} 2 / \mathrm{Q} 2 \mathrm{R} 37$. htm (accessed 24 Mar. 2017).

Grossnickle, S.C. 2005. Importance of root growth in overcoming planting stress. New For. 30:273-294. doi:10.1007/s11056-004-8303-2

Guittonny-Larchevêque, M., B. Bussière, and C. Pednault. 2016. Tree-substrate water relations and root development in tree plantations used for mine tailings reclamation. J. Environ. Qual. 45:1036-1045. doi:10.2134/ jeq2015.09.0477

Guittonny-Larchevêque, M., and C. Pednault. 2016. Substrate comparison for short-term success of a multispecies tree plantation in thickened tailings of a boreal gold mine. New For. 47:763-781. doi:10.1007/ s11056-016-9543-7

Hangs, R.D., J.J. Schoenau, K.C.J. Van Rees, and H. Steppuhn. 2011. Examining the salt tolerance of willow (Salix spp.) bioenergy species for use on saltaffected agricultural lands. Can. J. Plant Sci. 91:509-517. doi:10.4141/ cjps10135

Harada, E., A. Hokura, I. Nakai, Y. Terada, K. Baba, K. Yazaki, M. Shiono, N. Mizuno, and T. Mizuno. 2011. Assessment of willow (Salix sp.) as a woody heavy metal accumulator: Field survey and in vivo X-ray analyses. Metallomics 3:1340-1346. doi:10.1039/c1 mt00102g

Jordan, M.J., and M.P. Lechevalier. 1975. Effects of zinc-smelter emissions on forest soil microflora. Can. J. Microbiol. 21:1855-1865.

Kabata-Pendias, A., and H. Pendias. 2001. Trace elements in soil and plants, 3rd ed. CRC Press, Boca Raton, FL.

Kost, D.A., J.P. Vimmerstedt, and J.H. Brown. 1998. Site factor effects on establishment of planted and volunteer trees and shrubs on graded cast overburden and replaced topsoil in southeastern Ohio. Int. J. Surf. Min. Reclam. Environ. 12(2):79-86. doi:10.1080/09208118908944027

Kukier, U., R.L. Chaney, J.A. Ryan, W.L. Daniels, R.H. Dowdy, and T.C. Granato. 2010. Phytoavailability of cadmium in long-term biosolids-amended soils. J. Environ. Qual. 39(2):519-530. doi:10.2134/jeq2007.0671

Labrecque, M., I. Traian Teodorescu, and S. Daigle. 1995. Effect of wastewater sludge on growth and heavy metal bioaccumulation of two Salix species. Plant Soil 171:303-316. doi:10.1007/BF00010286

Landhäusser, S.M., J. Rodriguez-Alvarez, E.H. Marenholtz, and V.J. Lieffers. 2012. Effect of stock type characteristics and time of planting on field performance of aspen (Populus tremuloides Michx.) seedlings on boreal reclamation sites. New For. 43:679-693. doi:10.1007/s1 1056-012-9346-4

Larchevêque, M., A. Desrochers, B. Bussière, H. Cartier, and J.-S. David. 2013. Revegetation of non acid-generating, thickened tailings with boreal trees: A greenhouse study. J. Environ. Qual. 42:351-360. doi:10.2134/ jeq2012.0111
Larchevêque, M., A. Desrochers, B. Bussière, and D. Cimon. 2015. Plantation of trees in soil layers for the reclamation of non-acid generating wastes of a boreal gold mine. Ecoscience 21(3-4):217-231. doi:10.2980/21-(3-4)-3697

Lebrun, M., C. Macri, F. Miard, N. Hattab-Hambli, M. Motelica-Heino, D. Morabito, and S. Bourgerie. 2017. Effect of biochar amendments on As and $\mathrm{Pb}$ mobility and phytoavailability in contaminated mine Technosols phytoremediated by Salix. J. Geochem. Explor. (in press). doi:10.1016/j. gexplo.2016.11.016

Mahar, A., P. Wang, A. Ali, M. Kumar Awasthi, A. Hussain Lahori, Q. Wang, R. $\mathrm{Li}$, and Z. Zhang. 2016. Challenges and opportunities in the phytoremediation of heavy metals contaminated soils: A review. Ecotoxicol. Environ. Saf. 126:111-121. doi:10.1016/j.ecoenv.2015.12.023

Markert, B., G. Kayser, S. Korhammer, and J. Oehlmann. 2000. Distribution and effects of trace substances in soils, plants and animals. In: J.P. Vernet, editor, Trace elements: Their distribution and effects in the environment. 4th ed. Elsevier, Amsterdam. p. 3-31. doi:10.1016/S0927-5215(00)80004-1

Marmiroli, M., F. Pietrini, E. Maestri, M. Zacchini, N. Marmiroli, and A. Massacci. 2011. Growth, physiological and molecular traits in Salicaceae trees investigated for phytoremediation of heavy metals and organics. Tree Physiol. 31:1319-1334. doi:10.1093/treephys/tpr090

Mirck, J., and T.A. Volk. 2010. Response of three shrub willow varieties (Salix spp.) to storm water treatments with different concentrations of salts. Bioresour. Technol. 101:3484-3492. doi:10.1016/j.biortech.2009.12.128

Mosseler, A., J.E. Major, and M. Labrecque. 2014. Growth and survival of seven native willow species on highly disturbed coal mine sites in eastern Canada. Can. J. For. Res. 44:340-349. doi:10.1139/cjfr-2013-0447

Munns, R. 2002. Comparative physiology of salt and water stress. Plant Cell Environ. 25:239-250. doi:10.1046/j.0016-8025.2001.00808.x

Pietrzykowski, M., W. Krzaklewski, and B. Wos. 2015. Preliminary assessment of growth and survival of green alder (Alnus viridis), a potential biological stabilizer on fly ash disposal sites. J. For. Res. 26(1):131-136. doi:10.1007/ s11676-015-0016-1

Prasad, M.N., and K. Strzalka. 2002. Physiology and biochemistry of metal toxicity and tolerance in plants. In: M.N.V. Prasad and K. Strzałka, editors, Physiological responses of vascular plants to heavy metals. Kluwer Academic Publisher, p. 149-171. doi:10.1007/978-94-017-2660-3

Rajaniemi, T.K. 2007. Root foraging traits and competitive ability in heterogeneous soils. Oecologia 153(1):145-152. doi:10.1007/s00442-007-0706-2

Rakotonimaro, T.V., C.M. Neculita, B. Bussière, M. Benzaazoua, and G.J. Zagury. 2017. Recovery and reuse of sludge from active and passive treatment of mine drainage-impacted waters: A review. Environ. Sci. Pollut. Res. Int. 24(1):73-91. doi:10.1007/s11356-016-7733-7

Ritcey, G.M. 1989. Tailings management: Problems and solutions in the mining industry. Elsevier Science, Amsterdam.

Robinson, B.H., T.M. Mills, D. Petit, L.E. Fung, S.R. Green, and B.E. Clothier. 2000. Natural and induced cadmium-accumulation in poplar and willow: Implications for phytoremediation. Plant Soil 227:301-306. doi:10.1023/A:1026515007319

Sloan, J.L., and D.F. Jacobs. 2013. Fertilization at planting influences seedling growth and vegetative competition on a post-mining boreal reclamation site. New For. 44:687-701. doi:10.1007/s11056-013-9378-4

Stokes, A., C. Atger, A. Glyn Bengough, T. Fourcaud, and R.C. Sidle. 2009. Desirable plant root traits for protecting natural and engineered slopes against landslides. Plant Soil 324:1-30. doi:10.1007/s11104-009-0159-y

Tordoff, G.M., A.J.M. Baker, and A.J. Willis. 2000. Current approaches to the revegetation and reclamation of metalliferous mine wastes. Chemosphere 41:219-228. doi:10.1016/S0045-6535(99)00414-2

Wagner, A., B.A. Buchanan, and S. Buchanan. 2007. Rooting depth of 3 year old seedlings into overburden piles at a high elevation hard rock mine. In: R.I. Barnhisel, editor, National Meeting of the American Society of Mining and Reclamation, Gillette, WY, 30 Years of SMCRA and Beyond. 2-7 June 2007. ASMR, Lexington, KY. p. 884-890. doi:10.21000/ JASMR07010884

Zhivotosky, O.P., J.A. Kuzovkina, C.P. Schulthess, T. Morris, D. Pettinelli, and M. Ge. 2011. Hydroponic screening of willows (Salix L.) for lead tolerance and accumulation. Int. J. Phytorem. 13:75-94. 